\title{
Bracken (Pteridium aquilinum). The effect of steaming on the nutritive value of bracken hay
}

\author{
By D. R. WILLIAMS* AND R. A. EVANS \\ Department of Agricultural Chemistry, University College \\ of North Wales, Bangor \\ (Received 12 September 1956-Revised 22 September 1958)
}

The bracken fern (Pteridium aquilinum) has been known for a long time to be poisonous to cattle (Penberthy, I 893) and horses (Muller, I897) under farm conditions. Field cases of bracken poisoning in sheep are almost unknown; the more selective feeding habits of sheep may be responsible for their apparent immunity.

Bracken poisoning has been experimentally produced in cattle (Almond, 1894), horses (Hadwen \& Bruce, 1933), sheep (Moon \& Raafat, I95I) and in rats (Weswig, Freed \& Haag, 1946).

The signs of bracken poisoning in simple-stomached animals, such as the horse and rat, are fundamentally different from those observed in ruminants. In the horse (Evans, Evans \& Roberts, 1951) and the rat (Weswig et al. I946; Evans \& Evans, 1949) the signs are typical of thiamine deficiency and timely therapy with the vitamin produces complete recovery. It is now known that the bracken fern, in common with other pteridophytes, contains a thiaminase which converts thiamine into products which cannot replace the intact vitamin in mammalian nutrition (Evans, Jones $\&$ Evans, 1950).

Bracken thiaminase is thermolabile (Evans \& Jones, 1952) and steaming bracken for I h renders it harmless to rats (Evans et al. I950) although bracken dried in a revolving-drum grass drier still contains thiaminase actively toxic to rats (Evans, Evans, Thomas, Watkins \& Chamberlain, I958).

Bracken poisoning of cattle is characterized by haemorrhage and pyrexia with a severe leucopenia and thrombocytopenia due to depression of bone-marrow activity. The tissues of the affected animals are not deficient in thiamine. Thiamine therapy or even treatment with all known members of the vitamin-B group failed to cure the condition (Naftalin \& Cushnie, I954; Evans, Evans \& Hughes, 1954a,b; Evans, Thomas, Evans \& Edwards, 1958).

The factor responsible for ruminant bracken poisoning has been proved to be different from thiaminase (Evans, Evans et al. 1958). Neither the steaming of fresh green bracken (Naftalin \& Cushnie, 1954) nor the drying of fresh green bracken in a revolving-drum grass dryer (Evans, Evans et al. 1958) destroyed its toxicity to cattle. However, the steaming of bracken hay has been shown to lower its toxicity below a threshold level (Evans et al. I954a, b).

* Present address: Department of Chemistry, Wye College (University of London), near Ashford, Kent. 
Numerous investigations have been made into the composition of bracken at various stages of growth (Ferguson \& Armitage, 1944; Moon \& Pal, 1949; Shearer, 1945; Smith \& Fenton, 1944; Carpenter, Phillipson \& Thomson, 1950; Smith \& Agiza, 195 I).

Ferguson \& Neave (1944) investigated the nutritive value of fresh bracken and of bracken silage for sheep, but the low palatability of the diets limited the duration of their experiments and their results can only be tentatively accepted. Moon \& Pal (1949), using bullocks and sheep, found that the nutritive value of fresh fairly young green bracken, cut in July or August, was similar to that of good hay but that mature brown bracken cut in October had virtually no nutritive value.

The experiments described here were carried out to reassess the nutritive value of bracken hay and to determine the effect upon it of steaming, a treatment known to reduce its toxicity.

\section{EXPERIMENTAL}

\section{Preparation of bracken hay}

Bracken harvested in mid-July, 1953, at the University College Farm, Aber, Caernarvonshire, was made into hay in favourable dry weather. The hay was then chaffed, carefully mixed, bagged and stored in a warm dry room. Half of the total material was steamed for $\mathrm{I} h$ in a steam sterilizer and dried in a Unitherm oven (Birmingham and Blackburn Construction Co. Ltd) at $30^{\circ}$. The residual moisture content of both steamed and unsteamed bracken averaged $6 \%$.

\section{Animals}

Two Welsh mountain yearling wethers, of about $50 \mathrm{lb}$ live weight and in good condition, were used. Before the experiment, both animals were dosed with phenothiazine to reduce the worm burden.

\section{Feeding and collection of excreta}

To facilitate quantitative feeding with test diets and collection of food residues, the sheep were confined in metabolism cages. Each cage was fitted with a large aluminium feeding bin with high sides to minimize food scattering. To prevent the sheep dragging their food back into the cage, it was necessary to limit their movement by tethering them to the front of the cage by a collar and length of light chain. A bucket of water was fixed to the side of the cage within easy reach.

Urine excreted by the sheep passed through the wire-mesh floor on to a Perspex chute from which it drained into a collection bottle containing a small amount of chloroform and toluene as preservatives.

The faeces, uncontaminated by urine, were quantitatively collected in a canvas collection bag shaped over a stout copper wire frame. The bag was kept in position by a webbing harness. The equipment used was similar to that described by Raymond, Harris \& Harker (1953) but modified to suit the smaller sheep employed in this experiment. 


\section{Arrangement of trials}

The sheep were harnessed and kept in the cages for a fortnight on a ration of meadow hay, then for a week on bracken hay, to accustom them to experimental conditions. Water was supplied ad lib. throughout the trials. Feeding with bracken hay was unrestricted to simulate as closely as possible normal grazing habits. The daily consumption was about $500 \mathrm{~g}$. To ensure that feed was always available $75 \circ \mathrm{g}$ bracken hay were offered daily to each animal.

With each sheep two trials were done with each of the two bracken diets, unsteamed and steamed. A 7-day equilibration period on a particular diet was followed by a 9-day trial period. The equilibration period was long enough to ensure freedom from interaction in the digestive tract with the diet previously under test. Each 9-day trial period was divided into three subperiods of 3 days' duration. The weights of the sheep were recorded at the beginning and end of each trial period.

Because of evident selection of food material by the sheep, the feed residues for each subperiod were collected, weighed and stored for analysis.

In each subperiod the faeces were collected daily at feeding time and stored at $-20^{\circ}$ in air-tight tins to prevent bacterial decomposition.

The urine was collected over the whole 9-day trial period.

\section{Analytical technique}

Preparation of samples. For analysis, $500 \mathrm{~g}$ samples were taken from each ro $\mathrm{kg}$ bag of steamed or unsteamed bracken hay and from the food residues in each subperiod on the bracken ration. The air-dry samples of feed and residues were prepared for chemical analysis and calorimetry by grinding in a Christie and Norris laboratory mill fitted with a sieve with perforations $0.8 \mathrm{~mm}$ diam., and were stored in air-tight jars.

The frozen faeces collected from each sheep in each 3 -day subperiod were weighed and from each collection a sample, $5 \%$ of the total, was taken for nitrogen determination. The remainder was then divided into two equal portions for moisture determination, oven-dried and prepared for analysis and calorimetric measurement in the same way as the original feed.

The 9-day urine collection from each sheep was made up to a convenient volume with distilled water. Suitable portions were taken for nitrogen determination. The remainder was concentrated to a small bulk under reduced pressure in a climbingfilm evaporator; drying was completed rapidly at $105^{\circ}$. The dried residue was weighed and stored for calorimetric measurement.

Chemical analysis and calorimetric measurement. Moisture, crude protein, ether extract, crude fibre, nitrogen-free extract and ash were determined by standard methods (Minister of Agriculture, Fisheries and Food and the Secretary of State for Scotland, 1955). Gross energy was determined with a Mahler-Cook bomb calorimeter used in accordance with the instructions of the makers (Chas. W. Cook and Sons Ltd, Perry Bar, Birmingham). The bomb was calibrated by combustion of benzoic acid (B.D.H. Calorimetric Standard). 


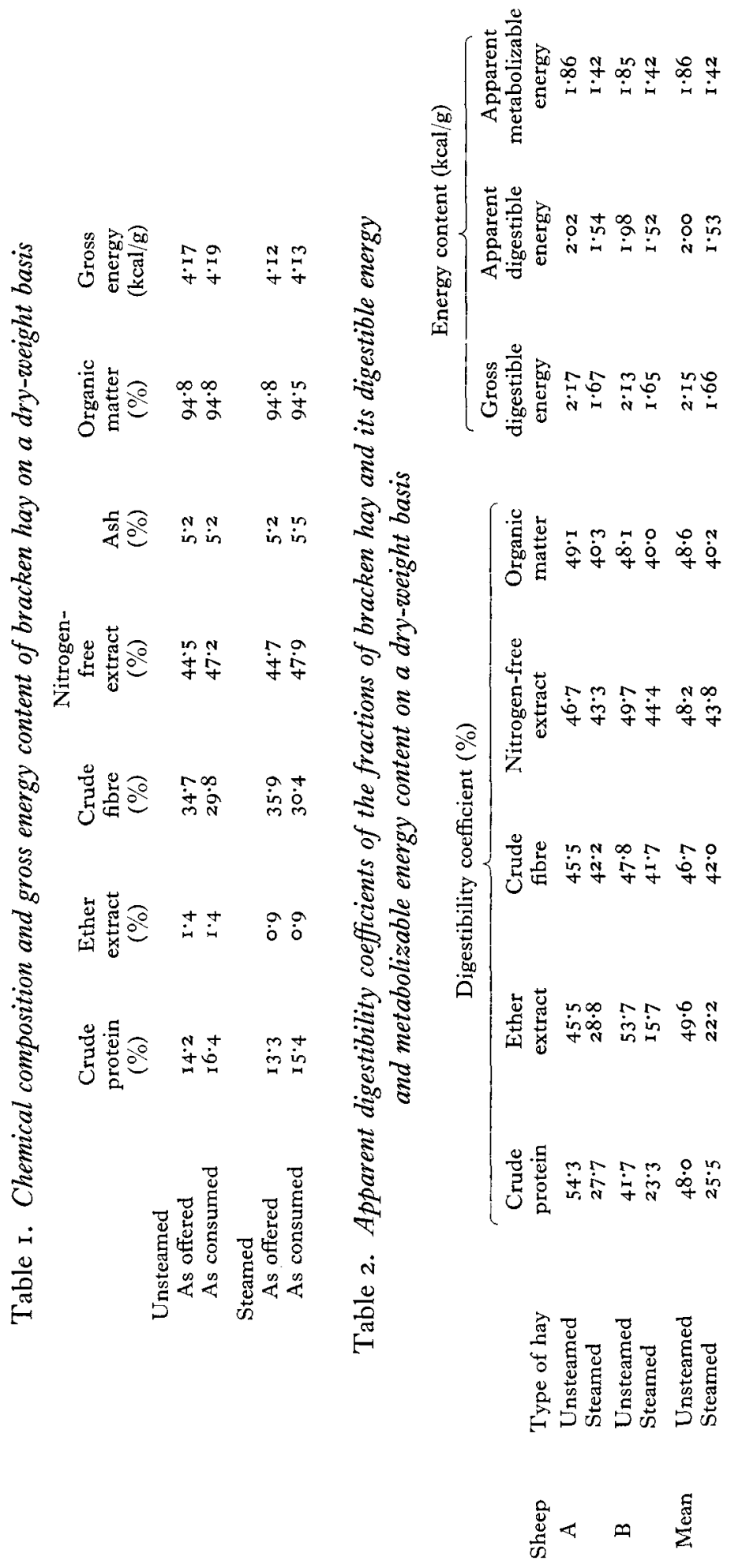


Chromatographic demonstration of tryptophan. Bracken protein was obtained from bracken hay by extraction with water at $\mathrm{pH} 7 \cdot 2$ followed by a precipitation with hydrochloric acid at $\mathrm{pH} 2 \cdot 5$. The precipitate was hydrolysed with $4 \%(\mathrm{w} / \mathrm{v})$ barium hydroxide for $15 \mathrm{~h}$. Barium was removed with sulphuric acid. The neutralized hydrolysate was shown to contain tryptophan by partition chromatography on Whatman no. I paper with a mixture of butanol, acetic acid and water (4:1:5 by volume) followed by spraying with I $\% p$-dimethylaminobenzaldehyde in $\mathrm{N}-\mathrm{HCl}$ (modified from Block \& Bolling, I951).

\section{RESULTS}

Throughout the experiment, the sheep maintained their condition and blood samples showed normal leucocyte and platelet counts. The variation in live weight was negligible, indicating that the trials were carried out at maintenance level.

With unsteamed bracken hay the mean daily consumption by the two sheep was different ( 354 and $554 \mathrm{~g}$ dry matter). With steamed bracken hay the amounts eaten were similar ( 539 and $50 \mathrm{r}$ g dry matter).

Table 3. Digestible nutrients and starch equivalent of bracken hay on a dry-weight basis

\begin{tabular}{|c|c|c|c|c|c|}
\hline \multirow[b]{2}{*}{ Type of hay } & \multicolumn{4}{|c|}{ Digestible nutrients } & \multirow[b]{2}{*}{$\begin{array}{l}\text { Starch } \\
\text { equivalent } \\
\text { (lb/100 lb) }\end{array}$} \\
\hline & $\begin{array}{c}\text { Crude } \\
\text { protein } \\
(\%)\end{array}$ & $\begin{array}{c}\text { Ether } \\
\text { extract } \\
(\%)\end{array}$ & $\begin{array}{l}\text { Crude } \\
\text { fibre } \\
(\%)\end{array}$ & $\begin{array}{l}\text { Nitrogen-free } \\
\text { extract } \\
(\%)\end{array}$ & \\
\hline Unsteamed & $7 \cdot 9$ & 0.7 & 13.9 & $22 \cdot 8$ & $35 \cdot 0$ \\
\hline Steamed & $3 \cdot 9$ & 0.2 & $12 \cdot 8$ & $21 \cdot 0$ & $25 \cdot 6$ \\
\hline
\end{tabular}

The chemical composition and gross energy content of the unsteamed and steamed bracken hay used in the trials are shown in Table I and contrasted with the mean values of the feed consumed in all the trials. The sheep selectively consumed the less fibrous material of higher protein content.

The apparent digestibility coefficients of the constituents of unsteamed and steamed bracken hay are summarized in Table 2. These values are not corrected for faecal excretion of metabolic origin. The values quoted are means over all trial subperiods, variations in food intake being taken into account. The energy content of bracken hay is also given in Table 2. The values for gross digestible energy quoted were computed from the calorimetric values as the difference between gross energy intake and gross energy output in the faeces, and thus have not been corrected for the unavailable energy content of gases produced by microbial action in the rumen. The values for apparent digestible energy were obtained from values for the gross digestible energy by correcting for gaseous energy loss, by means of the relationship between methane produced and carbohydrate digested found by Swift, Bratzler, James, Tillman \& Meek (1948). The values for apparent metabolizable energy were corrected for gaseous energy loss and for the energy content of the urine excreted; those for apparent energy were not corrected for excreted energy of metabolic origin.

In Table 3 are shown the digestible nutrients and the starch equivalents of the 
bracken hay consumed in the trials. The starch equivalents were calculated by Woodman's (1952) procedure but values for crude protein were used instead of those for true protein.

In Table 4 are summarized the results of the nitrogen balances on the two diets.

\begin{tabular}{|c|c|c|c|c|c|}
\hline \multirow[b]{2}{*}{ Type of hay } & \multirow{2}{*}{$\underset{\substack{\text { consumed } \\
\text { (g/day) }}}{\mathrm{N}}$} & \multirow{2}{*}{$\begin{array}{c}\mathrm{N} \\
\text { absorbed } \\
\text { (g/day) }\end{array}$} & \multirow{2}{*}{$\begin{array}{c}\mathrm{N} \\
\text { retained } \\
(\mathrm{g} / \text { day })\end{array}$} & \multicolumn{2}{|c|}{$\mathrm{N}$ retained as percentage of } \\
\hline & & & & $\mathrm{N}$ consumed & $\mathrm{N}$ absorbed \\
\hline $\begin{array}{l}\text { Unsteamed } \\
\text { Steamed }\end{array}$ & $\begin{array}{l}11.91 \\
12.81\end{array}$ & $\begin{array}{l}5 \cdot 64 \\
3 \cdot 32\end{array}$ & $\begin{array}{l}1 \cdot 57 \\
1 \cdot 26\end{array}$ & $\begin{array}{r}13 \cdot 2 \\
9 \cdot 8\end{array}$ & $\begin{array}{l}27 \cdot 8 \\
37 \cdot 8\end{array}$ \\
\hline
\end{tabular}

DISCUSSION

The chemical composition of the bracken hay used in these experiments was generally similar to that of the fresh August-cut bracken used by Moon \& Pal (1949) but the crude-protein content was higher.

Steaming the bracken hay decreased the content of crude protein and ether extract, possibly owing to leaching by condensed steam or through volatilization. The crudefibre content showed a corresponding increase.

The sheep consumed less dry matter on a bracken-hay diet than on one of meadow hay, but there was no evidence of diminishing appetite as the trials progressed such as was found by Ferguson \& Neave (1944). On the contrary, daily consumption was highest in the last experimental period, when the animals had already been eating bracken hay as the sole diet for over 2 months. No differences in live weight were observed over the 9-day trial periods, even though on unsteamed bracken hay the food consumption of the sheep differed. Neither were there appreciable differences in the digestibility coefficients of the various constituents of the hay.

The mean digestibility coefficient of crude protein was lowered very markedly by steaming the bracken hay. The sheep differed in their ability to digest crude protein (4I.O and $32.5 \%$, averaged over both diets) but this difference was consistent. The substantial lowering of the mean digestibility coefficient of the organic matter brought about by steaming the bracken hay could not be entirely accounted for by the effect on the crude protein, which formed only $17 \%$ of the organic matter consumed; the effects on the ether extract, crude fibre and nitrogen-free extract all contributed, though the depression due to the effect of steaming on any one of these fractions was not appreciable. The two sheep were similar in their ability to digest ether extract, crude fibre, nitrogen-free extract and organic matter.

The experiments of Ferguson \& Neave (r944) showed that the ensiling of bracken lowered the nutritive value by depressing the digestibility of organic matter, the effect being most marked upon the protein fraction. This effect is seen in overheated silage made from grass and other crops and is not peculiar to bracken (Watson \& Ferguson, 1937). Ferguson \& Neave (1944) did not consider that heat generated during ensilage of bracken was entirely responsible for the almost complete loss of digestibility of protein, but assumed that bracken contains a constituent which in some manner in the silo renders the protein indigestible to the animal. This factor 
does not appear to be fully operative when bracken hay is steamed, since the depression of digestibility caused by ensiling is much greater than that caused by steaming. No evidence was found by Ferguson \& Neave (1944) of toxicity of bracken silage to sheep, young cattle or dairy cows, but the periods of test were too short for any definite conclusions to be drawn. Jones (1952) showed that medium- or high-temperature bracken silage made with molasses, or bracken ensiled by the A.I.V. process, could be given successfully to rats as $40 \%$ of their diet. The diets permitted satisfactory growth rate and the toxicity to rats was entirely destroyed by ensilage. If bracken silage, safe to feed to farm stock, could be made without very great loss of nutritive value, the process might be of practical importance in providing winter feed from bracken cut for the purpose of eradication.

Our calorimetric results showed that steaming did not affect the gross energy content of bracken hay, but caused a considerable drop in the digestible and metabolizable energy content, as would be expected from its effect upon the digestibility coefficient of organic matter. Unsteamed bracken hay had a starch equivalent similar to that of good meadow hay, and very similar to that found by Ferguson \& Neave (1944) for fresh June-cut bracken leaf, and by Moon \& Pal (1949) for fresh Augustcut bracken. The latter workers found a lower digestibility of crude protein and a higher digestibility of nitrogen-free extract than was observed by us. Steaming of bracken hay produced an inferior foodstuff which was still, however, superior in starch equivalent to poor meadow hay or straw.

The results of the nitrogen-balance tests showed a net retention of nitrogen in all trials. The mean apparent net protein value (measured as ( $\mathrm{N}$ retained/ $\mathrm{N}$ consumed) $\times$ 100) of the bracken was lowered by steaming, but not as much as would be expected from the drop in the digestibility coefficient of crude protein because of the increase, caused by steaming, in the apparent biological value (measured as $(\mathrm{N}$ retained/N absorbed) $\times$ (00).

As described on p. 133, the presence of tryptophan in bracken was demonstrated chromatographically, and the results of microbiological assay (Evans, 195I) were thus confirmed. This result differed from that obtained by Smith \& Agiza (195I) who were unable to find tryptophan in protein extracted from bracken. Davies, Evans \& Parr $(1952 a, b)$ found that extracted bracken protein had a high biological value (71 \%) for rats. In the complete absence of an essential amino acid such as tryptophan it would not normally be possible for such high rates of nitrogen utilization to occur in rats.

SUMMARY

I. Two sheep were confined in metabolism cages and fed ad lib. during 9-day digestibility trails on unsteamed or steamed bracken hay.

2. Unsteamed bracken hay, made in July, had a nutritive value similar to that of good meadow hay. The sheep selected the less fibrous material of higher protein content.

3. Steaming to inactivate the toxic factor(s) resulted in a drop in nutritive value due to lowered digestibility of organic matter, especially of the crude-protein fraction. The steamed bracken hay was still superior to poor meadow hay or straw. 
4. The bracken hay, unsteamed or steamed, formed the sole diet of sheep for 72 days without ill effect, and was consumed at a rate adequate for weight maintenance.

5. Net retention of nitrogen occurred in all trials.

Our thanks are due to Professor W. C. Evans for sponsoring this work.

\section{REFERENCES}

Almond, I. (1894). F. comp. Path. 7, x65.

Block, R. J. \& Bolling, D. (r95I). The Amino Acid Composition of Proteins and Foods, 2nd ed. p. 449. Springfield, I1l.: C. C. Thomas.

Carpenter, K. J., Phillipson, A. T. \& Thomson, W. (1950). Brit. vet. F. 106, 292.

Davies, M., Evans, W. C. \& Parr, W. H. (1952a). Biochem. F. 52, xxiii.

Davies, M., Evans, W. C. \& Parr, W. H. (1952 b). Personal communication.

Evans, E. 'T. R., Evans, W. C. \& Roberts, H. E. (195I). Brit. vet. F. 107, 364.

Evans, I. A., Thomas, A. J., Evans, W. C. \& Edwards, C. M. (1958). Brit. vet. F. 114, 253.

Evans, W. C. (I95I). Personal communication.

Evans, W. C. \& Evans, E. T. R. (1949). Brit. vet. F. 105, I75.

Evans, W. C., Evans, E. T. R. \& Hughes, L. E. (1954a). Brit. vet. F. 110, 295.

Evans, W. C., Evans, E. T. R. \& Hughes, L. E. (1954b). Brit. vet. F. 110, 365.

Evans, W. C., Evans, I. A., Thomas, A. J., Watkins, J. E. \& Chamberlain, A. G. (1958). Brit. vet. F. II4, I 80 .

Evans, W. C. \& Jones, N. R. (1952). Biochem. F. 50, xxviii.

Evans, W. C., Jones, N. R. \& Evans, R. A. (1950). Biochem. F. 46, xxxviii.

Ferguson, W. S. \& Armitage, E. R. (1944). F. agric. Sci. 34, 165.

Ferguson, W. S. \& Neave, O. (1944). F. agric. Sci. 34, I72.

Hadwen, S. \& Bruce, E. A. (1933). Vet. $\mathcal{~ . ~ 8 9 , ~} 120$.

Jones, N. R. (1952). Anti vitamin factors present in plants and their significance in animal nutrition. Ph.D. thesis, University of Wales.

Minister of Agriculture, Fisheries and Food and the Secretary of State for Scotland (1955). The Fertilizers and Feeding Stuffs Regulations, 1955. Stat. Instrum. no. 1673.

Moon, F. E. \& Pal, A. K. (1949). F. agric. Sci. 39, 296.

Moon, F. E. \& Raafat, M. A. (1951). F. comp. Path. 6r, 88.

Muller, H. (1897). Landwirthschaftliche Giftlehre, quoted in Lander's Veterinary Toxicology, 2 nd ed. ( 1926$)$. London: Baillière, Tindall and Cox.

Naftalin, J. M. \& Cushnie, G. H. (1954). F. comp. Path. 64, 54.

Penberthy, J. (1893). F. comp. Path. 6, 266.

Raymond, W. F., Harris, C. E. \& Harker, V. G. (1953). F. Brit. Grassl. Soc. 8, 30 r.

Shearer, G. D. (1945). F. comp. Path. 55, 301.

Smith, A. M. \& Agiza, A. H. (195I). F. Sci. Fd Agric. 2, 503.

Smith, A. M. \& Fenton, E. W. (1944). F. Soc. chem. Ind., Lond., 63, 2 I 8.

Swift, R. W., Bratzler, J. W., James, W. H., Tillman, A. D. \& Meek, D. C. (1948). F. Anim. Sci. 7, 475.

Watson, S. J. \& Ferguson, W. S. (1937). F. agric. Sci. 27, 1.

Weswig, P. H., Freed, A. M. \& Haag, J. R. (1946). F. biol. Chem. 165, 737.

Woodman, H. E. (1952). Bull. Minist. Agric., Lond., no. 48, 12th ed. 